\title{
Influence of vernalization and bulb size on the production of lily cut flowers and lily bulbs
}

\section{Vernalização e tamanho do bulbo na produção de flores e de bulbos de lírio de corte}

\author{
Diogo Brito de Almeida ${ }^{1}$; José Geraldo Barbosa ${ }^{2 *}$; José Antônio Saraiva Grossi²; \\ Fernando Luiz Finger ${ }^{2}$; Joice Crescencio Heidemann ${ }^{3}$
}

\begin{abstract}
Exposure of bulbs to cold, a physiological phenomenon called vernalization, and bulb size are important factors in the production of lily bulbs and flowers. This study aimed to verify the influence of vernalization of bulbs on flowering cut lily plants, as well as the impact of size and shape of harvest on the production and quality of flowers and bulbs. In turn, the way the stems of the plants used for cutflower production are cropped is of higher importance for the production of new flower bulbs. In this sense, the experiment was conducted in Viçosa, MG, in a greenhouse in a randomized block design, in split splot scheme with three replications, in which the vernalization periods $(25,35$ and 45 days at $4 \pm$ $1 \mathrm{C}$ ) constituted the plots; bulb sizes (diameters of $3.2-3.8 \mathrm{~cm} ; 2.5-3.2 \mathrm{~cm} \mathrm{1.9-} \mathrm{and} 2.5 \mathrm{~cm}$ ), subplots and ways to harvest (full harvest of the stem at the required length for the commercial harvest of the flower, commercial stem harvest at the commercial length, maintaining $10 \mathrm{~cm}$ of stem in the soil; removal of the floral buds as soon as their appearance is observed and harvest at the end of the season), the sub subplots. The bulbs were planted in beds, with $15 \times 20 \mathrm{~cm}$ spacing. It was evaluated the number of plants that flowered and the number of flowers, the length and the diameter of the floral buds, fresh and dry weights, diameter and plant height as well as number, perimeter and amount of fresh and dry bulbs. There was a decrease in the plant height with the increase of the vernalization period and a reduction of the diameter of the planted bulbs, as well as of the number and the fresh and dry weights of the produced buds. The production of flowers and buds in number, size and weight was directly proportional to the size of the planted bulbs, while the form of harvest with removal of flower buds increased the number, the perimeter and the fresh and dry weights of the buds. Bulbs with diameter between $3.2-3.8 \mathrm{~cm}$, stored for 25 days in cold chamber enable greater production of flowers and the highest stem height, factors that favor the increase in market value.
\end{abstract}

Key words: Exposure to cold. Flowering. Way of harvest. Lilium longiflorum.

\section{Resumo}

A exposição dos bulbos ao frio, fenômeno fisiológico denominado vernalização, e o tamanho do bulbo são importantes na produção de flores de lírio. Por sua vez, a forma de colheita das hastes das plantas utilizadas para corte de flor é preponderante na produção de bulbos filhos. Este estudo teve como objetivo verificar a influência da vernalização dos bulbos em plantas de lírio em flor, bem como o impacto do tamanho e forma da colheita na produção e qualidade de flores e bulbos. O experimento foi conduzido

${ }^{1}$ M.e. em Fitotecnia, Universidade Federal de Viçosa, UFV, Viçosa, MG, Brasil. E-mail: diogobalmeida@gmail.com

2 Profs. Titulares, UFV, Viçosa, MG, Brasil. E-mail: jgeraldo@ufv.br; jgrossi@ufv.br; ffinger@ufv.br

3 Discente, Curso de Mestrado do Programa de Pós-Graduação em Fitotecnia, UFV, Viçosa, MG, Brasil. E-mail: sunjoyflower@ gmail.com

* Author for correspondence

Received: Sept. 21, 2016 Approved: May 02, 2017 
em Viçosa, MG em casa de vegetação, em blocos casualizados, com parcelas sub-subdivididas, com três repetições, em que os períodos de vernalização $\left(25,35\right.$ e 45 dias, a $\left.4 \pm 1^{\circ} \mathrm{C}\right)$ constituíram as parcelas; os tamanhos de bulbo (diâmetros de 3,2-3,8 cm; 2,5-3,2 cm e 1,9-2,5 cm), as subparcelas e as formas de colheita (colheita total da haste no ponto de colheita comercial da flor; colheita da haste no ponto comercial, mantendo $10 \mathrm{~cm}$ da haste no solo; retirada do botão floral assim que seu surgimento foi observado e colheita no fim do ciclo vegetativo), as sub subparcelas. Os bulbos foram plantados em canteiros, em espaçamento de $15 \times 20 \mathrm{~cm}$. Foram avaliados o número de plantas que floresceram e número de flores, comprimento e diâmetro do botão floral, massas fresca e seca, diâmetro e altura da planta e número, perímetro e massa fresca e seca de bulbos. Houve decréscimo na altura da planta com o aumento do período de vernalização e redução do diâmetro do bulbo plantado, assim como do número e da massa seca e fresca dos bulbos produzidos. Já, a produção de flores e bulbos, em número, tamanho e peso, foi diretamente proporcional ao tamanho do bulbo plantado, enquanto a forma de colheita, com retirada do botão floral aumentou o número, o perímetro e as massas frescas e secas dos bulbos. Bulbos com diâmetro entre 3,2 - 3,8 cm, armazenados por 25 dias em câmara fria possibilitam maior produção de flores e a maior altura de haste, fatores que favorecem o aumento do valor de mercado.

Palavras-chave: Exposição ao frio. Florescimento. Forma de colheita. Lilium longiflorum.

\section{Introduction}

In Brazil, floriculture deserves special attention due to the high investment in technology and the fact that its development is characterized as one of the most promising sectors of agribusiness. Thus, the segment of flowers and ornamental plants is expanding, with sales of approximately $\mathrm{R} \$ 5.4$ billion in 2014 and R\$ 5.2 billion in 2013, an increase of $4 \%$ compared to 2013 (IBRAFLOR, 2015).

Among ornamental flowers, lilies are considered the second most important bulbous plant in the world market in commercial terms and can be sold as potted plant or cut flower.

It is estimated that between 20 and 22 million lily bulbs are planted annually for the production of flowers. Of this total $60 \%$ is intended for the cutting market and the remaining $40 \%$ for the production of potted plants. The main producing regions of cut lilies in Brazil are the states of São Paulo, Minas Gerais, and Rio de Janeiro. Given the importance of lilies in the production of bulbs, plants for cut flowers or potted plant studies to develop techniques that optimize the productivity and quality of plants, especially the control of flowering has been increasing, considering that in order to blossom, lilies must be exposed to low temperatures, a phenomenon known as vernalization (TOMBOLATO et al., 2010).

According to Taiz and Zeiger (2013), vernalization is the physiological event through which flowering is induced by exposure of the seeds and assexual structures and/or plants to cold temperatures. The exposure of lily plants to natural cold induces the differentiation of vegetative buds into reproductive buds. Flowering occurs in November and the flowers are mainly sold during Memorial Day (November $2^{\text {nd }}$ ). The improvement of vernalization techniques enables the cultivation of lilies throughout the year, a factor that gives the producer broader control of the market and a greater profit.

Nevertheless, proper use of this technology to control the flowering depends on the knowledge of physiological factors that influence plant growth and development as nutritional reserves and interactions between plant hormones, directly related to temperature and to the size of the bulb. Bulb size is also related to the quality of the plant, to the height of the flower stem, to the number and size of flowers and even to the flowering process, suggesting the need for a minimum size that provides the nutritional reserves required to develop stems and flowers according to trade patterns. 
Therefore, this study aimed to verify the influence of vernalization on flowering cut lily plants, as well as the impact of bulb size and form of harvest on the production and quality of flowers and bulbs.

\section{Material and Methods}

Structuring of the treatments
The experiment was conducted from 17/02/2012 to $13 / 08 / 2012$ in a greenhouse from the Floriculture Department of the Federal University of Viçosa, in Viçosa, MG. Lilium longiflorum bulbs were used, cv. Ace which produces white inflorescences of cluster type, which were characterized according to Table 1.

Table 1. Average bulb fresh weight and perimeter for bulbs with different diameters.

\begin{tabular}{cccc}
\hline & \multicolumn{3}{c}{ Bulb diameter } \\
\cline { 2 - 4 } Characteristics & $3.2-3.8 \mathrm{~cm}$ & $2.5-3.2 \mathrm{~cm}$ & $1.9-2.5 \mathrm{~cm}$ \\
Perimeter $(\mathbf{c m})$ & 17.13 & 14.9 & 12.52 \\
Fresh weight $(\mathbf{g})$ & 50.38 & 34.73 & 19.94 \\
\hline
\end{tabular}

The bulbs were placed in plastic boxes, on $17 / 02 / 2012$, containing vermiculite soaked in water and placed in cold storage at a temperature of $5.0 \pm$ $1{ }^{\circ} \mathrm{C}$, where they remained for 25,35 and 45 days, corresponding to the periods of vernalization. They were then removed from the chamber and planted into beds at a depth of approximately $8 \mathrm{~cm}$, with spacing of $15 \times 20 \mathrm{~cm}$.

The planting of the bulbs happened on 13/03/2012; 23/03/2012 and 02/04/2012. Substrate consisted of a mixture of soil, sand and manure, in proportions $(5: 1: 1)$. For each square meter of bed were applied $120 \mathrm{~g}$ of superphosphate and $40 \mathrm{~g}$ of potassium chloride. The fertilization was done 4 times every 15 days, with fertilizer formulated Peters (20-20-20) and irrigation 2x per week for maintenance of moisture in the field capacity until the beginning of the harvest.

The only necessary cultural treatment was the manual elimination of weeds from the pots.

Based on the emergence of floral buds it was employed three forms of harvest for the plants in each period of vernalization and bulb sizes, as follows:

- full harvest of the stem at the length of commercial flower harvest;

- harvest at commercial length, keeping $10 \mathrm{~cm}$ of the stem in the soil;

- removal of the floral bud when they emerge and harvest at the end of the season, evidenced by the natural senescence of the leaves.

It was used an experimental greenhouse with a randomized block design, in a scheme of sub divided plots. Treatment of the plot constituted specific periods of vernalization of the plots according to bulb size, as well as to the form of harvest. It was used three replications and two plants per experimental unit.

\section{Evaluation}

The harvest of the plants was carried out based on the perception of the emergence of buds in plants that did not flower, or in the commercial cutting point, characterized by the beginning of opening of the first inflorescence sepals in the plants that flowered, and started at 80 days after planting. Evaluations consisted of the following features: number of plants that flowered in percentage, height and diameter of plants; number of flowers per plant; 
length and diameter of buds $(\mathrm{cm})$, fresh and dry matter weight of the flowers, stems and leaves, as well as number, perimeter, fresh and dry weights of bulbs.

\section{Statistical analysis}

It was performed the ANOVA and the mean values for the chosen production features, for the vernalization periods, for sizes of bulbs and forms of harvest have been compared through the Tukey test at a $5 \%$ probability. The statistical program Assistat has been used and to verify the relationship between the presented treatments and the percentage of plants that bloomed, number of flowers per plant, height of plant, number of bulbs produced and perimeter, fresh and dry weight of bulbs.

\section{Results and Discussion}

\section{Percentage of flowered plants}

The percentage of plants that flowered was dependent on the size of bulbs used, adjusted to the quadratic regression equation with a point of maximum diameter of $3.92 \mathrm{~cm}$ (Figure 1), with $100 \%$ of bulbs with $3.2-3.8 \mathrm{~cm}$ having flowered. These results corroborate those reported by Abreu et al. (2003), in which $97 \%$ to $100 \%$ of flowering was observed in plants resulting from bulbs that have been vernalized for 30 and 45 days, respectively. The influence of vernalization on the percentage of blooming plants can be explained by the alteration of the hormonal balance between cytokinin and gibberellin in bulbs as verified by Ferreira et al. (1986).

Figure 1. Percentage of lily plants cv. Ace that have flowered in relation to the diameter of the planted bulb.

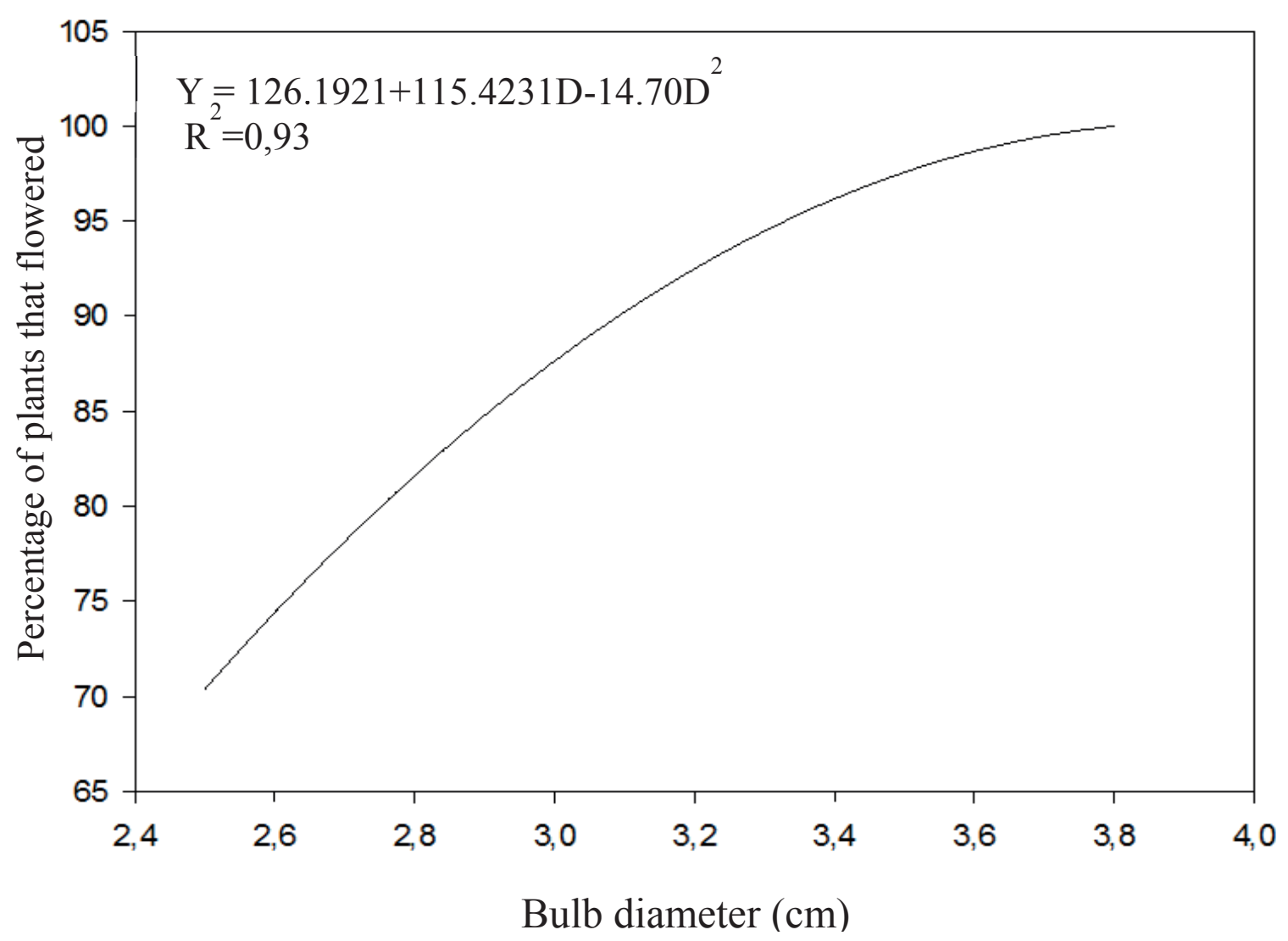


Plants in their various stages of growth and development have different capacity for photosynthesis, for absorption of nutrients from the soil, for the sensitivity of response to the action of hormones and changes in carbohydrate in the bulbs; being it to generate growth of the aerial part or for the development of new bulbs. Asker (2012), promoted bulbs excision 4, 6, 8 and 10 weeks after planting "Brunello" lily bulbs and kept plants without removing the bulbs. He noted that excisions during weeks 6 and 8 caused an increase in ovarian abortion, indicating the importance of the bulbs and the elements that have been provided and are assimilated for floral development.

\section{Number of flowers per plant}

The number of flowers was adjusted to meet the quadratic regression equation with minimum points of $2.85 \mathrm{~cm}$ and $2.05 \mathrm{~cm}$ for vernalization periods of 25 and 45 days respectively, and maximum points of 3.5 for 35 days of exposure to cold (Figure 2). It was observed a decrease in the number of flowers with increased vernalization period, although this feature proves to be proportional to the bulb diameter since, regardless of the vernalization period, there was an increase in the number of flowers with increasing size of the planted bulbs.

Figure 2. Estimate of the number of flowers produced per lily plant of cv. Ace in response to the vernalization period and bulb diameter.

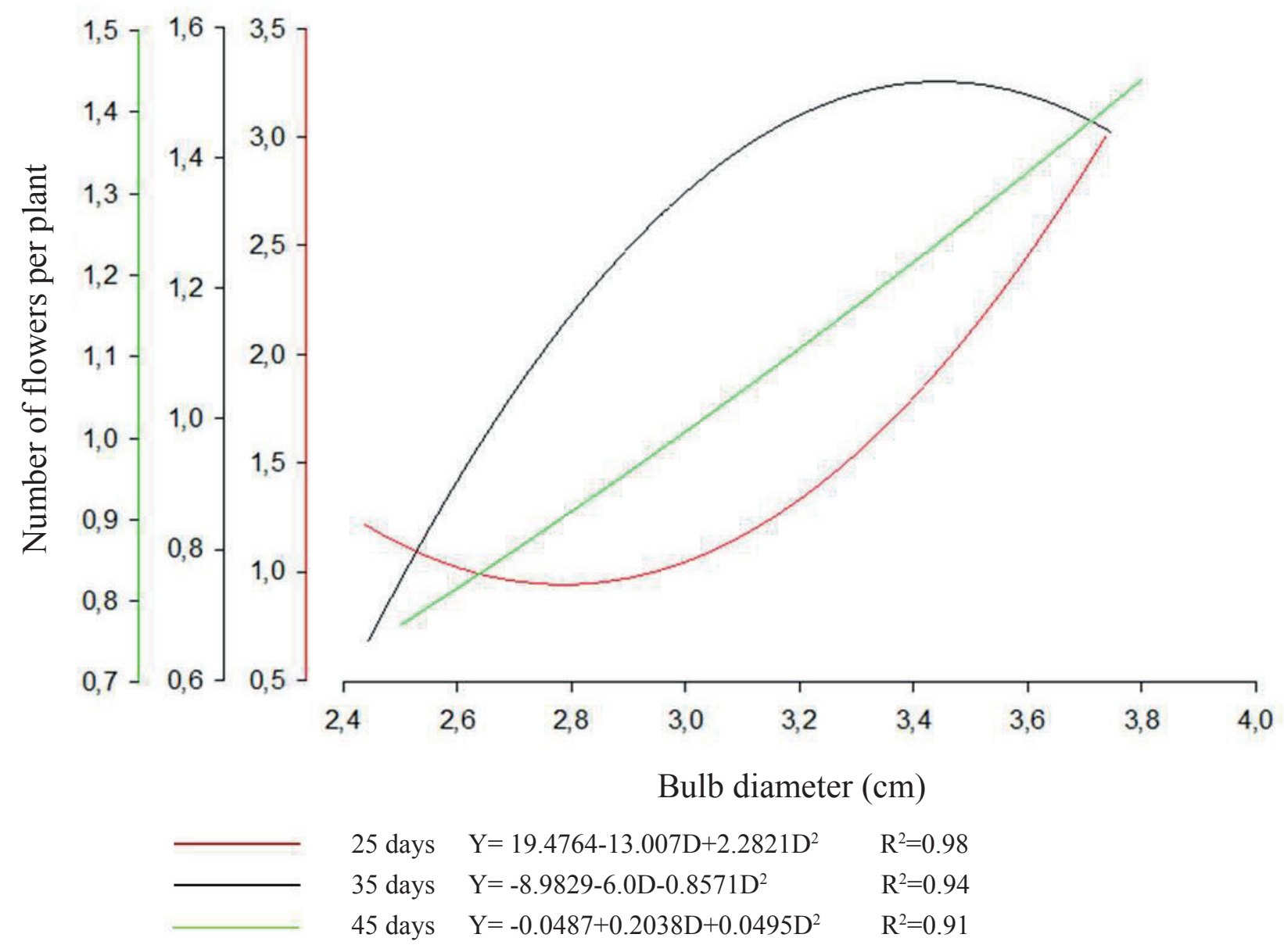


The effect of vernalization on the number of flowers per plant corroborates the account of Abreu (2000), who noted that for cv. Ace (L. longiflorum), increasing the storage period at low temperatures diminished this feature where plants from bulbs exposed to 0 days of vernalization produced 5.2 flowers while those that remained for 15,30 and 45 days have produced 4.6; 2.4; and 2.3 flowers per plant, respectively. Thus, the extension of the exposure period to cold and the reduction of the number of flowers per plant are typical features of L. longiflorum, as reported by Roh (1985) and Lee et al. (2010).

Exposure of bulbs to cold induces mobilization of soluble sugars from starch degradation and total reduction of nitrogen. Therewith, sucrose, fructose and glucose become available for the emergence and plant development (NARDI et al., 2004). The importance of the presence of bulbs for the number of flowers was also verified by Asker (2012), who found that the removal of lily bulbs during the growth of plants caused an increase in the abortion of flower buds and also a decrease in the number of flowers.

\section{Plant height}

The final stem length was adjusted to the quadratic regression equation for the different bulb sizes for each of the periods of vernalization, with minimum points of 2.86 and $2.26 \mathrm{~cm}$ diameter for periods of vernalization of 25 and 35 days, respectively, and a maximum point of $3.54 \mathrm{~cm}$ for plants grown from bulbs stored for 45 days in a cold room (Figure 3 ). There was a decrease in stem length with increase of the vernalization period. Moreover, there was an increase in stem length with increasing diameter of the bulb used. Lilies for cut flowers are classified according to stem length which varies from 40 to $90 \mathrm{~cm}$, and the higher the plant, so is its commercial value.

Figure 3. Estimate of the lily plant height, from cv. Ace in regards to the vernalization period and bulb diameter.

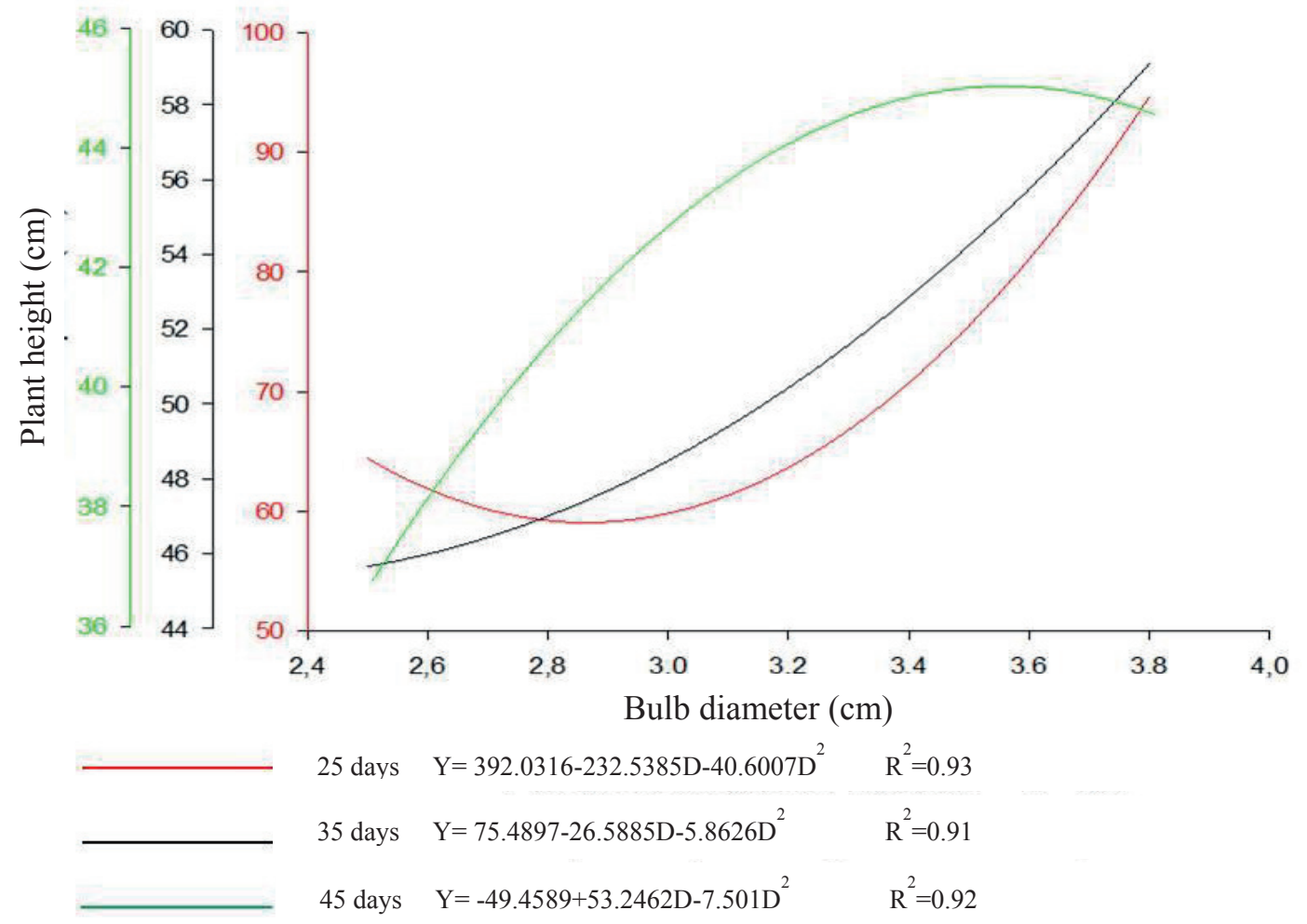


The results obtained with respect to vernalization corroborate those achieved by Abreu (2000), who found that increasing the vernalization period reduces the final plant height at which bulbs exposed to 30 and 45 days produced plants with a length of $98 \mathrm{~cm}$ and $77.4 \mathrm{~cm}$ respectively. The same correlation between the vernalization period and stem length was observed by Ausaque-Rodríguez et al. (2011) in Asian lilies cv. Castello, whose bulbs stored at $3^{\circ} \mathrm{C}$ for 4,6 and 8 weeks produced stems with reduced size when increased the period of exposure to cold.

Considering that the bulb size is a characteristic that is directly proportional to the weight, Takayama and Ohkawa (1990) also observed that the bigger the bulb weight, the greater the length of the stem for Lilium auratum. Asker (2012) showed the importance of the presence of lily bulbs during cultivation, since the removal of bulbs in different weeks after planting seemed to reduce plant growth.

\section{Number of bulbs}

The number of bulbs produced was influenced by the three sources of variation with interaction between them (Table 2). Plants from bulbs with $3.2-3.8 \mathrm{~cm}$ exposed to 25 days of vernalization whose form of harvest included the removal of the bud produced 6.44 new bulbs, a value $28 \%$ to $44 \%$ higher than those observed in plants with full harvest of the stem or stem harvest leaving $10 \mathrm{~cm}$ in the soil respectively. For 25 days of vernalization period, no difference was observed between the number of bulbs produced in the other two bulb sizes, regardless the form of harvest employed, with values ranging from 3 to 5 bulbs per plant. Plants from bulbs with 3.2 to $3.8 \mathrm{~cm}$ diameter subjected to 35 days of vernalization produced on average 5.33 bulbs when the excision of floral bud was made significantly higher compared to 2.83 and 1.61 bulbs obtained per plant with the full harvest of the stem or stem harvest leaving $10 \mathrm{~cm}$ of stem in the soil. In another way, for plants originated from bulbs exposed to 45 days of vernalization, there was no significant difference between the number of bulbs produced regardless of the diameter or the form of harvest, except when bulbs of plants from 3.2 to 3.8 $\mathrm{cm}$ were harvested leaving $10 \mathrm{~cm}$ of stem, in which a smaller production of bulbs was observed. Ahmad et al. (2009), on the other hand reported that when using bulbs of different sizes ( 1 to $4 \mathrm{~cm}$ diameter) for Polianthes tuberosa L. (Amaryllidacea), there was a directly proportional relationship between the size of bulbs planted and the number of bulbs produced.

Table 2. Number of lily buds produced based on the different vernalization periods, bulb diameters and forms of harvest.

\begin{tabular}{|c|c|c|c|}
\hline \multirow{2}{*}{$\begin{array}{r}\text { Vernalization (days) - } \\
\text { Bulb size (cm) }\end{array}$} & \multicolumn{3}{|c|}{ Form of harvest* } \\
\hline & 1 & 2 & 3 \\
\hline $25-(3.2-3.8)$ & $4.66 \mathrm{ab}$ & $3.66 \mathrm{~b}$ & $6.44 \mathrm{a}$ \\
\hline $25-(2.5-3.1)$ & $4.00 \mathrm{a}$ & $4.20 \mathrm{a}$ & $5.00 \mathrm{a}$ \\
\hline $25-(1.9-2.4)$ & $3.00 \mathrm{a}$ & $3.12 \mathrm{a}$ & $4.94 \mathrm{a}$ \\
\hline $35-(3.2-3.8)$ & $2.83 \mathrm{~b}$ & $1.16 \mathrm{~b}$ & $5.33 \mathrm{a}$ \\
\hline $35-(2.5-3.1)$ & $2.83 \mathrm{~b}$ & $1.16 \mathrm{~b}$ & $5.33 \mathrm{a}$ \\
\hline $35-(1.9-2.4)$ & $2.16 \mathrm{a}$ & $2.50 \mathrm{a}$ & $3.77 \mathrm{a}$ \\
\hline $45-(3.2-3.8)$ & $3.50 \mathrm{a}$ & $0.53 \mathrm{~b}$ & $4.67 \mathrm{a}$ \\
\hline $45-(2.5-3.1)$ & $3.66 \mathrm{a}$ & $1.75 \mathrm{a}$ & $3.50 \mathrm{a}$ \\
\hline $45-(1.9-2.4)$ & $2.50 \mathrm{a}$ & $1.39 \mathrm{a}$ & $3.50 \mathrm{a}$ \\
\hline
\end{tabular}

*(1- Full harvest of the stem; 2- Stem harvest leaving $10 \mathrm{~cm}$ of stem in the soil; 3 - Removal of the floral bud and stem harvest by the end of the season.

Means followed by the same letter do not differ from one another, across the row, at a $5 \%$ probability according to Tukey test. 


\section{Bulb perimeter}

The perimeter of the bulbs was only influenced by the applied form of harvest (Table 3). Plants whose buds were removed and the rest of the stem was maintained until senescence have produced significantly larger bulbs with $9.72 \mathrm{~cm}$ perimeter, a value $35 \%$ and $29 \%$ higher than for those in which the form of harvest was the full harvest and the full harvest leaving $10 \mathrm{~cm}$ of stem behind, respectively.
Whereas the formula for calculating the perimeter ( circumference $=2 \pi *$ radius) and diameter $(\mathrm{Dia}=$ $\pi *$ radius $\left.^{2}\right)$, it has been identified that the average diameter was $2.39 \mathrm{~cm}$ for the largest bulb perimeter achieved $9.72 \mathrm{~cm}$. This value falls within the bulb diameters used in this work. These results show the importance of the removal of flower buds in noncommercial plants in order to instigate the process of bulbification.

Table 3. Perimeter of the bulbs produced in lilies according to the forms of floral stem harvesting.

\begin{tabular}{cc}
\hline Form of Harvest* & Bulb perimeter \\
1 & $6.41 \mathrm{~b}$ \\
2 & $6.96 \mathrm{~b}$ \\
3 & $9.72 \mathrm{a}$ \\
\hline
\end{tabular}

$\mathrm{CV}(\%) 16,65$

*(1- Full stem arvest; 2 - Stem arvest eaving $10 \mathrm{~cm}$ of stem in the soil; 3 - moval of the floral bud and stem arvest by the end of the ason).

Means llowed by the same letter do not differ from one nother, across the row, at a $5 \%$ ability ording to the Tukey test.

The distribution of photo assimilates across the leaves for the development of flowers and of new bulbs takes place in parallel and during the growth of lily plants. These represent two strong drains during the plants final growth stage, as they compete for carbohydrates such as sucrose, glucose and the accumulation of starch, depending on the hormonal balance of auxins and cytokinins (TAIZ; ZEIGER, 2013). The excision of the flower bud allows the new bulbs in formation to become major drains and carbohydrates that were shared between the two organs are translocated to the bulbs, thus increasing its wet and dry mass and, consequently, its size. This dynamic translocation of carbohydrates was found by Addai and Scott (2011), who observed a drop in the concentration of starch over five months after planting for hyacinth bulbs (Hyacinthus $s p$.).

\section{Fresh and dry bulb weights}

The fresh bulb weights was influenced only by the form of stem harvest. Excision of the floral button leaving the vegetative parts (leaves and stems) enabled the production of bulbs whose average fresh weight was $17.39 \mathrm{~g}, 62 \%$ and $54 \%$ higher than the values obtained for the full harvest of the stem $(6.53 \mathrm{~g})$ and for the stem harvest leaving $10 \mathrm{~cm}$ of stem in the soil $(8.09 \mathrm{~g})$ (Table 4$)$. 
Table 4. Fresh weight roduction in bulbs of lily plants ccording to the forms of stem harvest.

\begin{tabular}{cc}
\hline Form of harvest* & Bulb fresh weight \\
1 & $6.53 \mathrm{~b}$ \\
2 & $8.09 \mathrm{~b}$ \\
3 & $17.39 \mathrm{a}$ \\
\hline
\end{tabular}

$\mathrm{CV}(\%) 55,1$

*(1- Full stem harvest; 2 - Stem harvest leaving $10 \mathrm{~cm}$ of the stem in the soil; 3 - Removal of the floral bud and stem harvest by the end of the season).

Means followed by the same letter do not differ from one another, across the row, at a 5\% robability according to the Tukey test.

Variations in the dry mass/weight of the produced bulbs were in turn influenced by the interaction of all treatments (Table 5), where plants grown from bulbs with 1.9 to $2.5 \mathrm{~cm}$ and 3.2 to $3.8 \mathrm{~cm}$ in diameter, subjected to 25 days of vernalization, regardless of the form of harvest showed no significant differences in the dry matter produced. Plants from intermediate sized bulbs ( 2.5 to $3.2 \mathrm{~cm}$ ) in turn, produced bulbs with higher dry mass when exposed to 25 days of vernalization, when the harvest included the removal of floral buds.

Table 5. Production of dry mass in the bulbs of lily plants according to the form of stem harvest.

\begin{tabular}{cccc}
\hline Vernalization (days) - & \multicolumn{3}{c}{ Form of Harvest* } \\
\cline { 2 - 4 } Bulb size (cm) & $\mathbf{1}$ & $\mathbf{2}$ & $\mathbf{3}$ \\
\hline $\mathbf{2 5}-\mathbf{( 3 . 2}-\mathbf{3 . 8})$ & $1.56 \mathrm{a}$ & $2.24 \mathrm{a}$ & $5.04 \mathrm{a}$ \\
$\mathbf{2 5}-(\mathbf{2 . 5}-\mathbf{3 . 1})$ & $1.06 \mathrm{~b}$ & $1.05 \mathrm{~b}$ & $5.25 \mathrm{a}$ \\
$\mathbf{2 5}-(\mathbf{1 . 9}-\mathbf{2 . 4 )}$ & $1.73 \mathrm{a}$ & $0.52 \mathrm{a}$ & $3.75 \mathrm{a}$ \\
$\mathbf{3 5}-(\mathbf{3 . 2}-\mathbf{3 . 8})$ & $0.72 \mathrm{a}$ & $1.51 \mathrm{a}$ & $3.51 \mathrm{a}$ \\
$\mathbf{3 5}-(\mathbf{2 . 5}-\mathbf{3 . 1})$ & $0.44 \mathrm{~b}$ & $1.07 \mathrm{~b}$ & $5.95 \mathrm{a}$ \\
$\mathbf{3 5}-(\mathbf{1 . 9}-\mathbf{2 . 4 )}$ & $1.12 \mathrm{a}$ & $0.97 \mathrm{a}$ & $3.36 \mathrm{a}$ \\
$\mathbf{4 5}-(\mathbf{3 . 2}-\mathbf{3 . 8})$ & $0.36 \mathrm{~b}$ & $0.53 \mathrm{~b}$ & $4.75 \mathrm{a}$ \\
$\mathbf{4 5}-(\mathbf{2 . 5}-\mathbf{3 . 1})$ & $0.82 \mathrm{~b}$ & $0.80 \mathrm{~b}$ & $8.36 \mathrm{a}$ \\
$\mathbf{4 5}-(\mathbf{1 . 9}-\mathbf{2 . 4 )}$ & $0.50 \mathrm{~b}$ & $0.79 \mathrm{a}$ & $3.36 \mathrm{a}$ \\
\hline
\end{tabular}

*(1- Full stem harvest; 2- Stem harvest leaving $10 \mathrm{~cm}$ of stem in the soil; 3- Removal of the floral bud and stem harvest by the end of the season).

Means followed by the same letter do not differ from one another, across the row, at a $5 \%$ probability according to the Tukey test.

Similarly to the bulbs exposed to 25 days of cold, those that have been stored for 35 days also showed the same relationship previously mentioned: larger production from planted bulbs measuring 2.5 $3.2 \mathrm{~cm}$ and whose form of harvest included excising the flower buds, with dry matter yield of $5.95 \mathrm{~g}$.

The results for the dry mass of the bulbs were similar to those reported by Ahmad et al. (2009), who observed that the bulb size used was directly proportional to the size and the weight of the new bulbs produced, in the cultivation of $P$. tuberosa L. Nevertheless, Addai and Scott (2011) reported the increase of the concentration of glucose, fructose, sucrose and starch, in addition to humidity of up to $10 \%$ in flowers over a period of 12 weeks after planting L. longiflorum. With excision of the floral buds, the new bulbs in formation became main drains and carbohydrates that were shared between the two organs became translocated to the bulbs, 
increasing both their dry and wet masses.

As a conclusion, it is possible to assume that the flowering cycle decreased with the increase of the vernalization period. A total of 89 and 150 days are required for the flowering process, when the bulbs are vernalized for 25 and 45 days respectively.

The use of bulbs with larger diameter and exposed to shorter vernalization periods resulted in an increase in the number of flowers and in the length of plants.

Lower production of bulbs occurred by planting smaller bulbs which underwent a longer vernalization period when the form of harvest included the elimination of floral buds.

Larger number, size and mass of the bulbs are favored by the removal of the floral bud and the harvest of the plant at the end of the vegetative cycle.

Bulbs with diameters between 3.2 and $3.8 \mathrm{~cm}$, stored for 25 days in cold storage, allow greater production of flowers and greater stem length, factors that favor the increase in the product market value.

\section{References}

ABREU, R. M. Efeito do periodo de vernalização sobre o crescimento e florescimento de quatro variedades de lírio. 2000. Dissertação (Mestrado em Fitotecnia) Universidade Federal de Viçosa, Viçosa, MG.

ABREU, R. M.; BARBOSA, J. G.; REIS, F. P.; PUIATTI, M.; ÁLVARES, V. S. Influência do frio sobre a quebra de dormência de bulbos de quatro variedades de lírio. Revista Ceres, Viçosa, MG, v. 50, n. 288, p. 261-271, 2003.

ADDAI, I. K.; SCOTT, P. Regulation of carbohydrates partitioning and metabolism of the common hyacinth. Agriculture and Biology Journal of North America, Milford, v. 2, n. 2, p. 279- 297, 2011.

AHMAD, I.; AHMAD, T.; MUHAMMAD, A.; MUHAMMAD, S.; AKRAM, A. Effect of bulb size on growth, flowering and bublis production of tuberose. Sarhad Journal of Agriculture, Surrey, v. 25, n. 3, p. 391398, 2009.
ASKER, H. M. Effect of bulb removal date on growth and flowering of Asiatic hybrid lily cv. Brunello. African Journal of Agricultural Research, Lagos, v. 7, n. 43, p. 5796-5799, 2012.

AUSAQUE-RODRÍGUEZ, O.; BALAGUERA-LÓPEZ, H. E.; ÁlVAREZ-HERRERA, J. G.; FISCHER, G. La temperatura de vernalización em bulbos reutilizados de lírio (Lilium sp.) afecta la distribución de matéria seca y la producción de flor. Revista Colombiana de Ciencias Horticolas, Tunja, v. 5, n. 2, p. 251-262, 2011.

FERREIRA, F. A.; CASALI, V. W. D.; SOARES, J. G. Dormência de bulbos de alho. Informe Agropecuário, Belo Horizonte, v. 12, n. 142, p. 3-7, 1986.

INSTITUTO BRASILEIRO DE FLORICULTURA IBRAFLOR. Mapeamento e quantificação da cadeia de flores e plantas ornamentais do Brasil. São Paulo: Ibraflor, 2015. 14 p. Disponível em: <http://www.ibraflor. com/publicacoes/vw.php?cod=246>. Acesso em: $19 \mathrm{fev}$. 2017.

LEE, A. C. K.; SUH, J. K.; ROH, M. S. Flowering and changes in respiration in Asiatic hybrid lilies as influenced by bulb vernalization. Scientia Horticulturae, Amsterdam, v. 123, n. 3, p. 366-371, 2010.

NARDI, C.; BURIOL, G. A.; BELLÉ, R. A.; STRECK, N. A.; SCHUH, M. Vernalização afeta a mobilização de reservas de açúcares e nitrogênio e a emergência de plantas de lírio (Lilium longiflorum thunb.) snow queen. Ciência Rural, Santa Maria, v. 34, n. 4, p. 1027-1033, 2004.

ROH, S. M. Flowering response of mid-century hybrid lilies to bulb vernalization and shoot photoperiod treatment. HortScience, Alexandria, v. 20, n. 4, p. 710$713,1985$.

TAIZ, L.; ZEIGER, E. Plant physiology. Redword City: The Benjamin/Cummings Publishing Company, 2013. $918 \mathrm{p}$.

TAKAYAMA, S.; OHKAWA, K. Growth and flowering of in vitro propagated Lilium auratum bulbs in soil. Plant Tissue Culture Lettes, Tokyo, v. 7, n. 3, p. 187-192, 1990.

TOMBOLATO, A. F. C.; UZZO, R. P.; JUNQUEIRA, A. H.; PEETZ, M. S.; STANCATO, G. C.; ALEXANDRE, M. A. V. Bulbosas ornamentais no Brasil. Revista Brasileira de Horticultura Ornamental, Campinas, v. 16, n. 2, p. 127-138, 2010. 